\title{
FACTORS ASSOCIATED WITH THE USE OF ANTENATAL CARE IN EAST SUMBA, EAST NUSA TENGGARA
}

\section{Maria Christina E. Sukartiningsih",2), Pius Weraman3), Rafael Paun3)}

\author{
${ }^{1)}$ District Health Office, East Sumba \\ ${ }^{2)}$ Nursing Program, School of Health Sciences, \\ Ministry of Health, Waingapu \\ ${ }^{3)}$ Graduate Program/ Faculty of Public Health, \\ Nusa Cendana University
}

\begin{abstract}
Background: Antenatal care (ANC) is very important to pregnant women as it helps prevent mother and child mortality, prevent complications, helps foster a good relationship between the husband and wife, mother and child and father. Good antenatal care includes regular screening which can detect and prevent early complications such as hypertension and pregnancy diabetes; both of which can dramatically affect the fetus. Early detection means regular monitoring and treatment. This study aimed to analyze factors associated with the use of ANC in East Sumba, East Nusa Tenggara.

Subjects and Method: This was an cross sectional study conducted in East Sumba, East Nusa Tenggara. A sample of 254 pregnant women were selected for this study by simple random sampling. The dependent variable was use of ANC. The independent variables were being a housewife, receiving husband's support, and social support. The data were collected by questionnaire and analyzed by a multiple logistic regression.

Results: The use of ANC was associated with being a housewife (b=0.88; 95\% $\mathrm{CI}=1.30$ to $4.48 ; \mathrm{p}=0.005)$, receiving husband's support $(\mathrm{b}=0.72 ; 95 \% \mathrm{CI}=0.25$ to $0.95 ; \mathrm{p}=0.035)$, and social support $(\mathrm{b}=1.52 ; 95 \% \mathrm{CI}=0.10$ to $0.51 ; \mathrm{p}<0.001)$.

Conclusion: The use of ANC is associated with being a housewife, receiving husband's support and social support.
\end{abstract}

Keywords: housewife, husband's support, social support, antenatal care, utilization

\section{Correspondence:}

Maria Christina E. Sukartiningsih. Nursing Program, School of Health Sciences, Ministry of Health, Waingapu, East Nusa Tenggara.

E-mail: endang.inovari@gmail.com. Mobile : +6281246659223. 